\title{
Identification of Critical Diffuse Pollution Sources in an Ungauged Catchment by Using the Swat Model- A Case Study of Kolleru Lake, East Coast of India
}

\author{
Meena Kumari Kolli ${ }^{1 *}$, Christian Opp ${ }^{1}$ and Michael Groll ${ }^{1}$ \\ ${ }^{1}$ Department of Geography, Philipps-Universität Marburg, Deutschhausstraße 10, 35037 Marburg, \\ Hesse, Germany.
}

Authors' contributions

This work was carried out in collaboration among all authors. Author MKK designed the study, data acquisition, performed the statistical analysis and wrote the first draft of the manuscript. Authors CO and MG managed the analyses of the study. Author CO managed the literature searches. All authors read and approved the final manuscript.

Article Information

DOI: $10.9734 / A J G R / 2020 / v 3 i 230105$

Editor(s):

(1) Dr. Hani Rezgallah Al-Hamed Al-Amoush, Al al-Bayt University, Jordan.

Reviewers:

(1) Zein El Arby, Université de Nouakchott Al Aasriya, Mauritania.

(2) K. Srinivasa Rao, Miozram University, India.

Complete Peer review History: http://www.sdiarticle4.com/review-history/58126

Original Research Article

Received 10 April 2020

Accepted 16 June 2020

Published 30 June 2020

\begin{abstract}
Freshwater ecosystems are facing severe threats from human activities. As a consequence of this, they can get disturbed. In developing countries, like India, freshwater lakes are endangered primarily by agricultural activities, which often accelerate erosion and the runoff. The massive application of pesticides and chemical fertilizers to agricultural lands is one of the reasons for eutrophication in Kolleru Lake. The different natural and anthropogenic influences increase the highly complex ecosystem of the lake. Therefore, the objectives of this study are to ascertain the priority control areas, aiming at socio-economic development for the protection of the lake water quality by applying the Best Management Practices (BMPs).

For this purpose, the Soil and Water Assessment Tool (SWAT) was used to identify the critical areas of the lake's catchment in terms of pollution from agricultural runoff into the tributaries of the Kolleru Lake and the lake itself. The results demonstrated that the diffuse pollution load in the western and downstream watersheds the highest and that agricultural land was the primary pollutant source besides the accumulation of nutrients in the downstream areas. The differences in the sub-basin
\end{abstract}


loads were observed in the catchment mainly depends on the topographic features, soil properties, land use, vegetation, and drainage patterns. From where the major outlet sub-basin has the highest accumulation of nitrate-nitrogen $\left(\mathrm{NO}_{3} \mathrm{~N}\right)$, and total phosphorus (TP) emissions were quantified. The temporal distribution of runoff and diffuse sources were estimated from $2008-2014$. The runoff mainly governed diffuse pollution was found to be a significant contributing factor to the lake. Further, suggestions were provided for the implementation of agricultural management practices to minimize pollution levels.

\section{Graphical Abstract:}

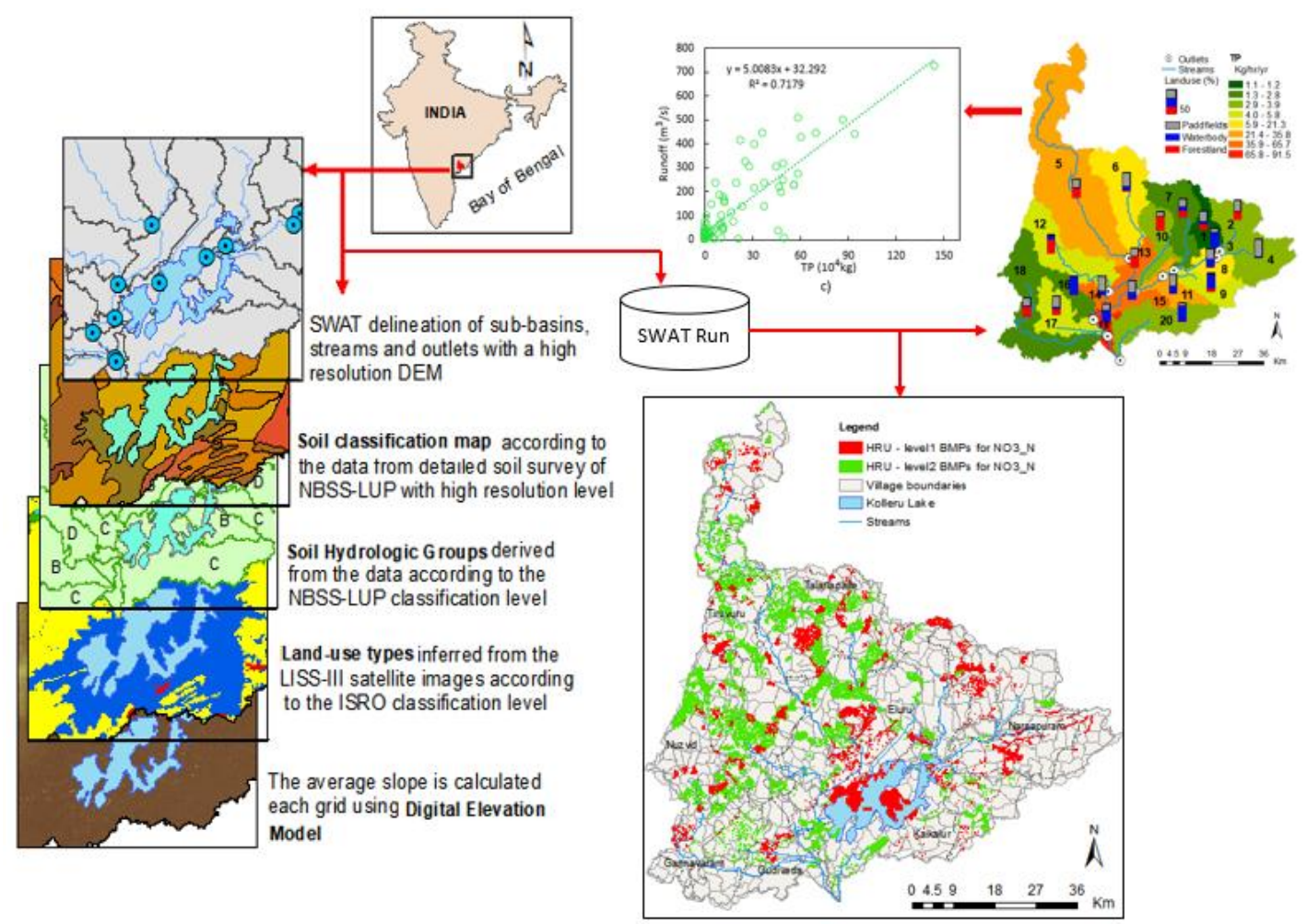

(Own Source: Diagrammatic representation showing the interrelationship of the SWAT run model)

Keywords: Kolleru Lake; eutrophication; diffuse pollution; water quality; hydrological model; BMPs; watershed management.

\section{INTRODUCTION}

In recent decades the effective pollution abatement measures to the water quality are sizeable $[1,2,3]$ But, in developing countries like India, the water quality pollution levels are so high, creating existential threats to biodiversity, thus lead to decreasing economic progress as well as costs of human lives [4]. India is one of the foremost agriculture-based economies in the world, with high fertilizer applications for increasing production to meet the growing population demand and the excessive nutrients from agricultural lands, leading to prominent diffuse pollution to the surface water quality $[5,6]$. The high alarming rate of increasing pollutant load of surface water from industrial accompanies is known from the concentration based discharge control of point sources, which is already an important task to control and to achieve water quality targets [7]. Additionally, the reduction of diffuse pollution sources is required.

Although urbanization and demographic changes are substantial influences within the lake's catchment, land-use changes cause extreme disturbances of the catchment's ecosystems and the lake itself. Most studies demonstrate that land-use changes $[8,9,10]$ as a driving factor for the environmental, including the physical and chemical characteristics of surface water bodies and their internal structure. 
Improper management of natural resources, coupled with an ever-increasing population, is responsible for the deterioration of water quality. Most of the freshwater resources are under stress caused by urbanization, and large-scale industrialization processes are a worldwide concern $[11,12,13]$.

The complexity exists in several ecosystem functions of the surface water bodies adversely affected foremost water quality in freshwater lakes which, in turn, and among others, influence ponds, rivers, streams and slowly enter into the groundwater $[14,15,16]$. Diffuse pollution caused by agricultural activities can be carried into adjacent water bodies by surface runoff and erosion [17,18]. Such excess of nutrients accelerates eutrophication and algae blooming in freshwater ecosystems. Besides, point sources are another significant reason for the deteriorating water quality in surface water bodies. However, the spatial and temporal distribution of diffuse pollutants is a challenge. It is important to monitor these distributions even for a large catchment area, due to changing climate, land-use, and strong relations to anthropogenic activities $[19,20]$. Therefore, it is essential to determine the severe diffuse pollution sources of a catchment and to apply the best management practices (BMPs) to protect lake water quality.

The Kolleru Lake catchment in West Godavari and Krishna districts of Andhra Pradesh state in India has been taken as a case study for understanding and modeling of the Spatiotemporal variability in the pollutant loads, which will be a prerequisite for better management of agricultural, industrial, and water resources.

In recent decades, many studies have used the Soil and Water Assessment Tool (SWAT) [21] to model the management of agricultural catchments for identifying polluted areas. The SWAT model is a useful tool for the estimation of both nitrogen and phosphorus (N \& P) emissions and the degree of eutrophication. It is a necessary prerequisite for the selection of BMPs from small scale areas $[22,23,24]$ to large scale catchments [25,26]. The US Environmental Protection Agency (EPA) recognized the SWAT model and incorporated it into the EPA's BASINS (Better Assessment Science Integrating Point and Nonpoint Pollution Sources) [25]. Apart from that, several studies were extended into the SWAT-based optimization tool for obtaining costeffective strategies for sustainable management $[27,28]$. However, due to continuous simulations and operations on a daily basis, it is an essential tool for the identification of pollutant sources.

The main objective of this study serves a better understanding of diffuse pollution sources in the Kolleru Lake catchment, and a typical flood balancing catchment between the Krishna and the Godavari basins. Here the aim of the present work carried out to estimate diffuse pollution in Kolleru Lake for the catchment level. Further, the study assimilated the critical sub-basin measures on the Hydrological Response Unit (HRU) level priority areas, and to conclude the planning of BMPs. Furthermore, suggestions are provided for the implementation of better lake management practices in the catchment.

\section{STUDY AREA}

\subsection{Kolleru Lake Area}

The Kolleru Lake has situated between $16^{\circ} 24^{\prime}$ $10^{\prime \prime}$ and $17^{\circ} 23^{\prime} 44^{\prime \prime}$ North latitude, and $80^{\circ} 41^{\prime}$ 5.5" and $81^{\circ} 39^{\prime} 27.5^{\prime \prime}$ East longitude in the south-eastern part of India (Fig. 1). It is the largest freshwater lake in India, as well as which forms the largest shallow freshwater lake in Asia. The sub-basins catchment area of $5,052 \mathrm{~km}^{2}$ and a water spread area of $901 \mathrm{~km}^{2}$ at $+10 \mathrm{MSL}$ (mean sea level). The average water depth of the lake is about $1 \mathrm{~m}$, and a maximum depth of $3 \mathrm{~m}$ can be monitored during the southwest monsoon period [29]. The minimum and a maximum temperature range from $14^{\circ} \mathrm{C}$ to $22^{\circ} \mathrm{C}$ from November till February and $35^{\circ} \mathrm{C}$ to $46^{\circ} \mathrm{C}$ from March till October, respectively. The annual mean precipitation is $1,094 \mathrm{~mm}$. The lake receives water from seasonal rivers, namely, Budameru and Thammileru. Apart from this, 68 minor irrigation channels are flowing into the lake. It has only an outlet river, the Upputeru, which connects the Kolleru Lake to the Bay of Bengal. The lake has rich in biodiversity, and thereby, the international Ramsar Convention in November 2002, declared it as a wetland of international importance.

The two perennial rivers of the Krishna and the Godavari formed its catchment, which gives the lake a unique characteristic and has led to its role as a natural flood-balancing reservoir between these river basins. The catchment area is one of the most developed agricultural regions in Andhra Pradesh state, familiar as "Rice Bowl of India." With a massive fertilizer application to increase crop yield, the Kolleru lake catchment accounts for $22.7 \%$ of chemical fertilizer consumption in the state of Andhra Pradesh. 
According to the Andhra Pradesh Pollution Control Board (APPCB), reports that in excess of 17,000 tons/yr of fertilizers enter into the lake. Because of the high proportion of agricultural land and diverse agro-climatic conditions in this region, encourage the cultivation of different crops, a large number of chemical fertilizers considerably replaced by the traditional organic manure. In recent decades, besides the sewage inflow from nearby towns, diffuse agricultural pollution was accounted for a significant pollution source. In most cases, adding more quantities of $N$ \& $P$ fertilizers to the soils does not result in increased crop yields and significantly led to proliferating eutrophication of the lake $[30,31,6]$.

The Kolleru lake is one of the most polluted lakes among the Pulicat and Chilika Lakes on the east coast of India. Therefore it is under the control of the Ministry of Environment, Forest and Climate Change (MoEF \& CC), along with Central Pollution Control Board (CPCB) and State Pollution Control Boards (SPCBs). These organizations are responsible for the legal and regulatory framework for environmental protection in India [32,33]. MoEF is accountable for the preparation of environmental policies through the Central Empowered Committee (CEC) in coordination with the Kolleru Lake Development Committee (KLDC), whereas the "Operation Kolleru" was implemented. The main objective of this voluntary program was to minimize the pollution from fishponds across the lake, the Supreme Court of India initiated the "Operation Kolleru" in 2006 to clear all encroachments and their water pollutants. It divided into three phases between 16 February 2006 and 13 June 2006. As a result, approximately 1,776 fish ponds became destroyed, and further 89.08 lakh $(100,000)$ cubic meters of natural earth forming embankments were removed [34].

\subsection{Significance of the Study}

It is generally known that the following essential criteria are prerequisites for the Kolleru Lake pollution control measures and implement the adequate BMPs between point and diffuse sources:

- In the catchment, point source pollution is distinguishable. They substantially contribute to water pollution. The reduction of pollution sources should be feasible and cost-effective
- The rise of illegal fishponds within the lake area should be controlled and monitored

- For reducing diffuse pollution, sources must be identified, and the usage of chemical fertilizers in croplands should be replaced by traditional organic methods.

Due to the lack of a comprehensive environmental policy, the Kolleru lake is still facing severe threats by agricultural runoff. In the catchment area, paddy cultivation carried two times in a year, the first crop cultivated between July and September is known as a summer crop, whereas the second crop grown between October and March is a winter crop [34]. According to Rao [35], the usage of chemical fertilizers significantly varied between these two seasons, and the first crop utilizes the chemical fertilizers nearly about $40 \mathrm{~kg} / \mathrm{ha}$, while the second crop uses two times higher than the first crop which is about $120 \mathrm{~kg} / \mathrm{ha}$. Besides, around the catchment area, approximately used of 1,16 , $800 \times 10^{3} \mathrm{~kg} / \mathrm{ha} / \mathrm{yr}$ inorganic fertilizers, and onefourth of them added in the lake through runoff and leaching [36]. The level of chemical fertilizer application is far beyond the maximum trend in this region, and the decrease of fertilizer application would be beneficiated.

Secondly, the water quality of the lake is deteriorated by point sources; thus, untreated industrial effluents released into the lake from nearby cities [34]. According to the list of critical pollution industries of the Kolleru Lake, there are 36 industrial pollutants located in the catchment. The major industries such as rice mills, paper industries, sugar factories, milk factories situated around the lake, alternately sewage sludge from nearby cities have contributed to its depletion and pollution. The pollution sources of the lake have highlighted by several studies and still continuous effort on point source pollution control not yet implemented - the management of the Kolleru Lake wetland ecosystem has received inadequate attention in the Central Water Commission (CWC) agenda. Thereby, it is subjected to severe anthropogenic pressure.

As more and more studies conducted on the Kolleru Lake ecosystem [30,37,38,39], it is possible to use the accumulated information for the development of pollution control measures and their responses to environmental changes. Apart from the point and diffuse sources, damages and losses due to massive flooding during the monsoon seasons, and partly drying out during summertimes, as a result of inadequate management planning and action, 


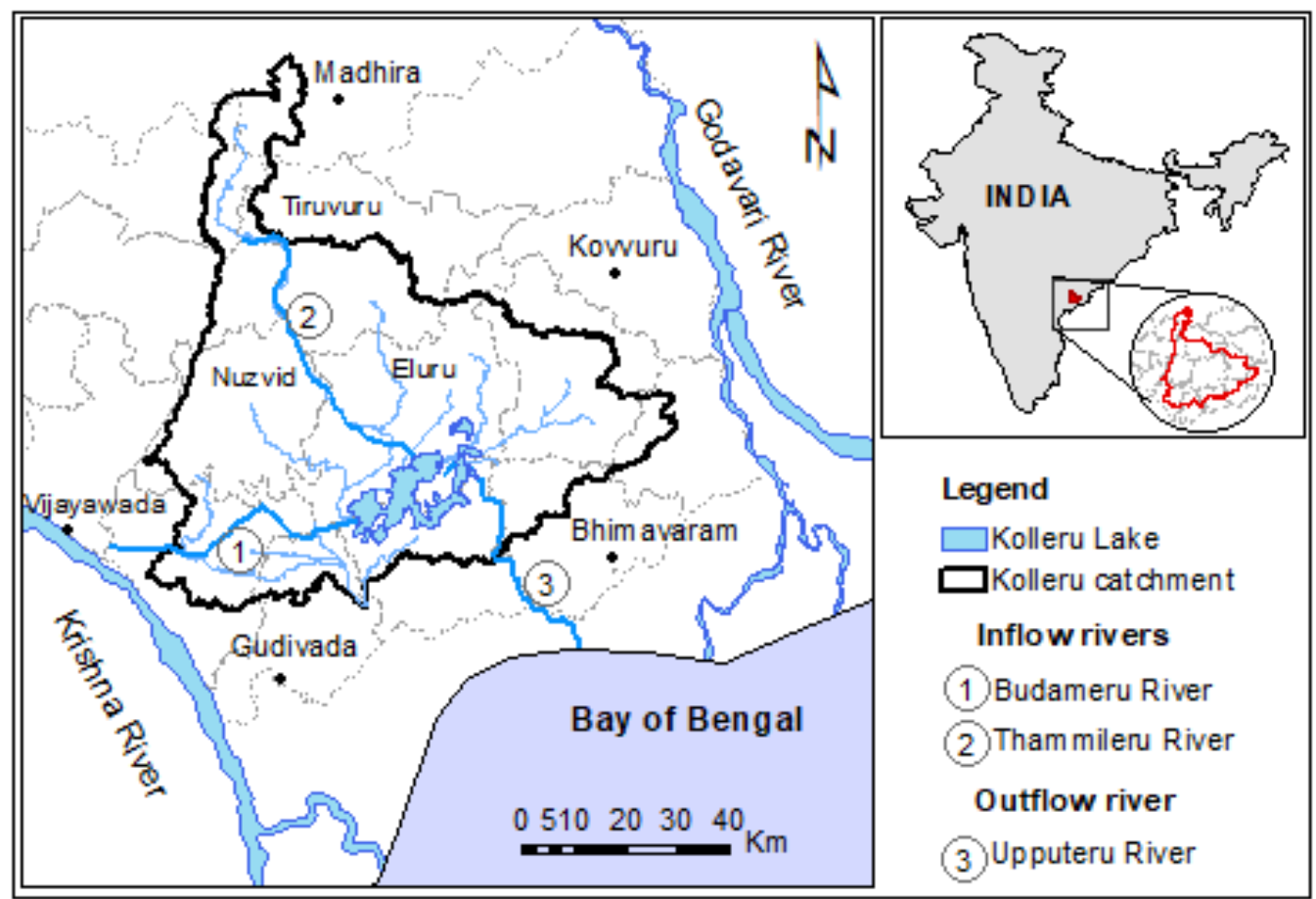

Fig. 1. Location of the kolleru lake

are seen as areas of improvement [40]. These natural and anthropogenic processes are influencing the lake. Both local drivers and features originating in the whole catchment of the lake occur. Since the 1990s, the lake has gone through enormous changes; more information about these changes can be found in Azeez et al. [34]. Based on the complexity of the existing threats of the lake, first, it is necessary to identify priority or test areas for applying management practices in the Kolleru Lake catchment, at least for lake protection. The present work emphasis on the priority control areas aiming at socioeconomic development linking with the "Operation Kolleru for demolishing the fish ponds to reestablish the past glory of the lake" (hereafter the "Operation Kolleru scheme") and in the long turn protection of the lake water quality by applying the Best Management Practices (BMPs).

\section{MATERIALS AND METHODS}

\subsection{Workflow to Action Plan}

After the "Operation Kolleru," the lake water still received serious threats by diffuse pollution. Therefore, the state government authorities approved that the lake was not polluted by the fishponds, due to agricultural runoff and urban infrastructure. Kolleru Lake pollution mitigation plans were formulated between 1982 and 2015. The efforts were taken in 2006 to resolve the pollution by fishponds. Still, the other sources of pollution left for discussion between researchers, stakeholders, and the state government authorities. Therefore the present work elaborates about the identification of priority areas of diffuse pollution from 2008 to 2014 (after Operation Kolleru), based on the SWAT model in Fig. 2.

The plan of action included in four stages: problem definition, preparing a database and SWAT model execution, identification of priority areas, and formulation of pollution mitigation measures. The first stage included the knowledge deficit in this area, discussed with the Kolleru Lake development programs, especially with the Kolleru Lake Forest Department (KLFD), Kolleru Lake Development Committee (KLDC), researchers, and water managers. Researchers and water managers provided the necessary data for understanding and visualizing the pollution levels in the catchment area-the second stage devoted to the database preparation and model execution in regular time intervals. The third stage included the identification of priority areas based on the results obtained from the SWAT model. Further, 
the results and necessary action plans will be discussed with the researchers, stakeholders, and state government authorities. The last stage was the implementation of an action plan for protecting the lake water against pollution.

\subsection{SWAT Model Setup}

The SWAT model was developed by the Agriculture Research Service of the United States Department of Agriculture [21]. This approach was adopted to simulate the diffuse pollution load in the Kolleru lake catchment. It is a physically-based and semi-distributed model that operates regularly and capable of continuous simulation over long periods [41]. In this study, the SCS (Soil Conservation Service) (USDA-SCS 1972) curve number was used to calibrate the surface runoff from daily rainfall data, further potential evapotranspiration from Penman-Monteith, and sedimentation from the Modified Universal Soil Loss Equation (MUSLE) [42]. The model equations are extensively documented on the official SWAT website (http://swatmodel.tamu.edu).

The data used (Table 1) in the SWAT model are in two different formats known as spatial and a temporal database. The spatial data includes the DEM (Digital Elevation Model) generated using stereo images of ASTER DEM with a spatial resolution of $30 \mathrm{~m}$. Present Land-use is mainly classified into agricultural land (for paddy cultivation), fishponds, urban, barren land (unused or uncultivated land), and forest areas (Fig. 2a). The soil types were categorized into 38 classes (Fig. 2b). The data provide insights into soil depth, drainage, texture, slope, erosion, salinity, etc. The temporal data include weather parameters, such as daily precipitation, maximum \& minimum temperature, relative humidity, wind speed, and solar radiation. The mainly used rain gauge stations were Bhimavaram, Eluru, Gudivada, Nuzvid, and Tadepalligudem. The catchment weather information used from daily monitoring data for the period 2008-2014. Information on crop patterns, fertilizer application, fish farming, social economics, and industrial pollution was based on previous literature and data collected from local statistics yearbooks [34], and on-field investigations as well.

The catchment area is composed of 38 different soil types, dominantly with clayey texture. According to this data, 46.7 percent of the catchment is largely extended to the well-drained condition, 19.9 percent is moderately welldrained, while 27.8 percent is composed of imperfectly drained, and 2.4 percent is excessively drained. Very deep soils (55 percent) predominantly identified within the catchment area with clay dominance in texture and pore spaces are in coarse and medium size. Present up-slope in the headwaters are covered by shrub vegetation and forest areas. The runoff

Table 1. Description of available data in the kolleru lake catchment

\begin{tabular}{|c|c|c|c|c|}
\hline $\begin{array}{l}\text { Data } \\
\text { availability }\end{array}$ & Scale & $\begin{array}{l}\text { Spatial } \\
\text { Resolution }\end{array}$ & Data description & Data Source \\
\hline DEM & $1: 12,500$ & $30 \mathrm{~m} \times 30 \mathrm{~m}$ & $\begin{array}{l}\text { Elevation, slope, } \\
\text { streams, lengths }\end{array}$ & $\begin{array}{l}\text { National Remote Sensing } \\
\text { Center (NRSC), } \\
\text { Hyderabad }\end{array}$ \\
\hline Land use & $1: 50,000$ & $30 \mathrm{~m} \times 30 \mathrm{~m}$ & $\begin{array}{l}\text { Landuse } \\
\text { classifications }\end{array}$ & $\begin{array}{l}\text { Indian Space Research } \\
\text { Organization, (ISRO) } \\
\text { Bangalore } \\
\end{array}$ \\
\hline Soil properties & $1: 500,000$ & $250 \mathrm{~m} \times 250 \mathrm{~m}$ & $\begin{array}{l}\text { Soil physical and } \\
\text { chemical properties }\end{array}$ & $\begin{array}{l}\text { National Bureau of Soil } \\
\text { Survey and Landuse } \\
\text { Planning (NBSS\&LUP), } \\
\text { Nagpur }\end{array}$ \\
\hline Weather data & - & Daily records & $\begin{array}{l}\text { Precipitation, minimum } \\
\& \text { maximum } \\
\text { temperature, wind, } \\
\text { relative humidity, solar } \\
\text { radiation }\end{array}$ & $\begin{array}{l}\text { Indian Meteorological } \\
\text { Department (IMD), } \\
\text { Hyderabad }\end{array}$ \\
\hline $\begin{array}{l}\text { Management } \\
\text { practice }\end{array}$ & - & $\begin{array}{l}\text { Seasonal } \\
\text { variation }\end{array}$ & $\begin{array}{l}\text { Planting, fertilizer } \\
\text { application and } \\
\text { harvesting }\end{array}$ & $\begin{array}{l}\text { Andhra Pradesh } \\
\text { Agriculture Contingency } \\
\text { Plan (Yearbook), } 2008\end{array}$ \\
\hline
\end{tabular}




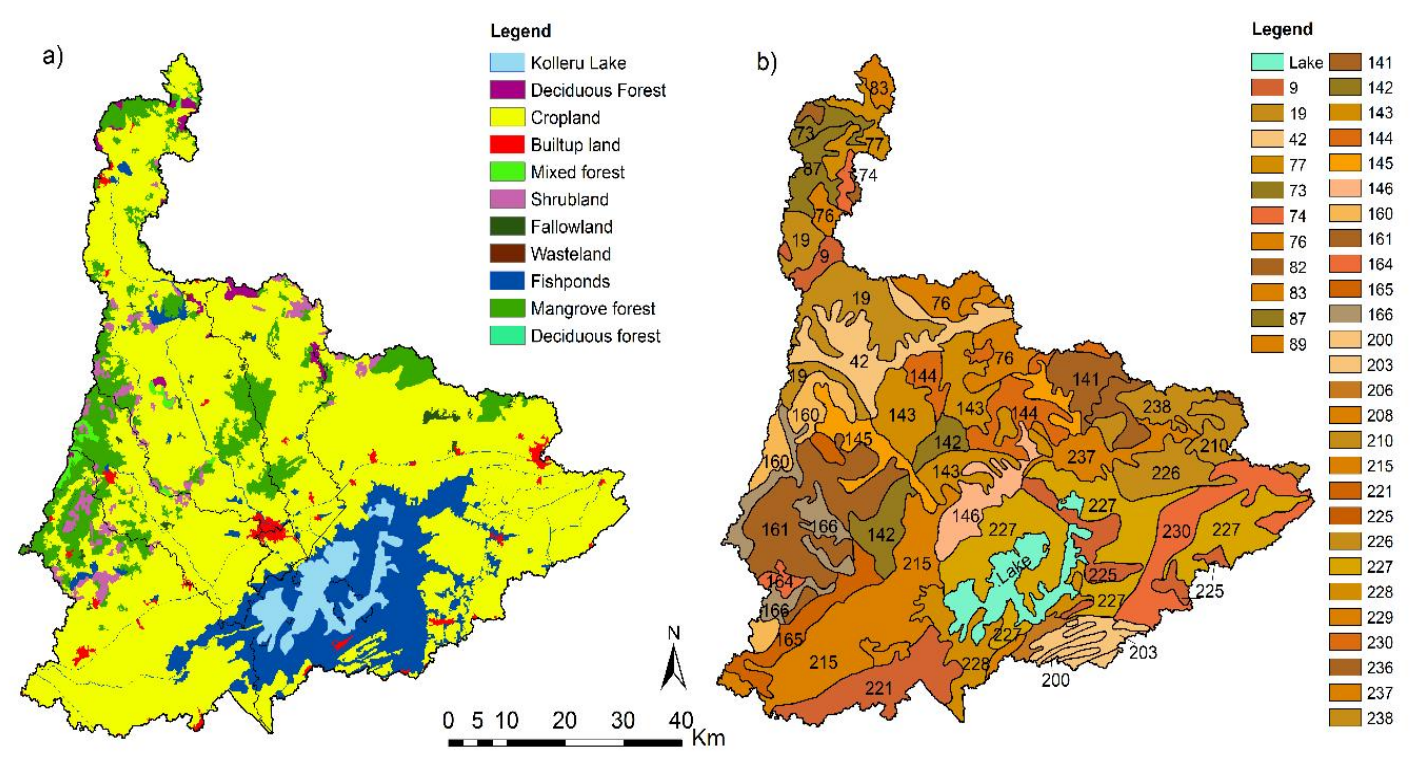

Fig. 2. a) Land use and land cover map b) Soil classification map of the kolleru lake catchment [43]

from the upper catchment passes the agricultural fields of the middle part before entering into the lake. Agricultural land is the dominant land use cover $(68 \%)$ of the catchment, followed by fishponds $(16 \%)$, mangrove forests on gently sloped areas $(10 \%)$, and the urban area does not exceed $3 \%$ of the total area.

Using a DEM with $30 \mathrm{~m}$ spatial resolution, SWAT delineated the catchment into 20 sub-basins depending on the flow direction, stream network, and drainage outlets. Slopes were classified into four gradient categories: $<3 \%, 3-$ $5 \%, 5-10 \%$, and $>10 \%$. Hydrologic Response Units (HRU) obtained from adjusting thresholds of $12 \%$ land-use, $15 \%$ soil, and $15 \%$ slope. There are 1,281 feature classes (HRU) that were delineated, while each $\mathrm{HRU}$ is being independent of the SWAT model, with a similar slope, land-use, and soil characteristics. For sufficient calibration analysis in the Kolleru Lake catchment; however, it is an ungauged region, further because of the lack of existing discharge data, the manual calibration analysis was performed in SWAT. For each time step, one-factor changes while keeping other factors remains constant. SWAT is a hydrological model that estimates the water quality parameters for both gauged and ungauged catchments.

\subsection{BMPs Setups and Stakeholders Engagements}

The first methodological approach has identified the agricultural management priority areas for applying BMPs to facilitate the relevant information to the stakeholders. The central and state government organizations had formulated the Kolleru Lake development programs and aimed to bring an optimized solution to conserve the lake resources. One such program is the Kolleru Lake Development Committee (KLDC), which checks the encroachments, regulating or monitoring the pollution level, and clearing the lake weeds every year. This study implemented the agricultural runoff attributes applied for the first time Kolleru Lake catchment. The generated information the awareness of the decisionmakers and stakeholders on value additions and controlling variables of the Kolleru Lake catchment.

Furthermore, the potential outcome of the "Operation Kolleru" program aimed to reestablished the past glory of the lake. A priority response of an integrated water management plan (IWMP) on the catchment level became possible for an optimal set of the lake ecosystem. However, the IWMP contains an activity to enlighten the stakeholder's perception towards 
lake degradation. Moreover, the state government agencies should incorporate with the stakeholders to adopt sustainable development activities that would need a priority response.

\section{RESULTS AND DISCUSSION}

The present work will be emphasized on the subbasin level. HRUs priority level of management strategy is presented below. Further, suggestions were discussed to achieve the best conservation practices of the lake ecosystem.

\subsection{Manual Calibration}

The seven most sensitive parameters that were tested during the surface runoff simulation are presented in Table 2. According to the results, SOL_K, ESCO, and SOL_AWC, GWQMN, and $\mathrm{CH}$ _K2 were identified as the most sensitive parameters. In the SWAT model, the SCS-CN method is used to estimate the permeability of the soil, as well as available moisture conditions. CN2 value for this study is relatively low sensitivity due to the small area of dry land significantly influences the runoff. On the other hand, the Kolleru is a wetland catchment has a very well-drained condition. Therefore, a change in the CN2 value would not significantly affect the hydrological components. For the study area, the results may be the updating feature of the CN2 in the SWAT model and the small area of dry land.

\subsection{Sub-basin Level BMPs}

The SWAT model quantified the spatial distribution of N\&P emissions in the Kolleru Lake catchment. This study examined that the diffuse pollution from agricultural runoff is an essential contribution to the total loads of nitrate-nitrogen $\left(\mathrm{NO}_{3} \mathrm{~N}\right)$ and total phosphorus (TP). According to Fig. $3 \mathrm{a}$, the amount of $\mathrm{NO}_{3} \mathrm{~N}$ is extremely different in each sub-basin ranged from 3.5 $\mathrm{kg} / \mathrm{ha} / \mathrm{yr}$ to $429 \mathrm{~kg} / \mathrm{ha} / \mathrm{yr}$, respectively. Among the five river sub-basins, the $\mathrm{NO}_{3} \mathrm{~N}$ was the highest in the Ramileru basin, with up to $429 \mathrm{~kg} / \mathrm{ha} / \mathrm{yr}$ in some sub-basins, and the lowest in the Gunderu basin, with less than $8.5 \mathrm{~kg} / \mathrm{ha} / \mathrm{yr}$ in each subbasin. The average range of each tributary river basin ranked from high to low based on the load intensities is outlined in Table 3. However, the annual average load of $\mathrm{NO}_{3} \mathrm{~N}$ in the Ramileru basin is $238.8 \mathrm{~kg} / \mathrm{ha} / \mathrm{yr}$. The amount is larger than $40 \mathrm{~kg} / \mathrm{ha} / \mathrm{yr}$ in most sub-basins of Budameru and Thammileru. For example, $55.6 \%$ of the $\mathrm{NO}_{3} \mathrm{~N}$ export from the entire catchment came from sub-basins No. 19, 14, 16, 13, 12, 5, 17, and 8 , each contributing $>28.7 \mathrm{~kg} / \mathrm{ha} / \mathrm{yr}$ of the areal $\mathrm{NO}_{3} \mathrm{~N}$ export. $\mathrm{NO}_{3}-\mathrm{N}$ in the lake mainly originates from the chemical fertilizers used in the Kolleru Lake catchment, where the agricultural land majorly accounts for paddy cultivation.

Table 2. runoff and sediment calibrated parameters used in kolleru lake catchment

\begin{tabular}{lll}
\hline No & parameter & definition \\
\hline 1 & $\mathrm{CN}_{2}$ & Surface runoff curve number for moisture condition II \\
2 & SOL_K & Saturated hydraulic conductivity of the soil surface $(\mathrm{mm} / \mathrm{hr})$ \\
3 & CH_K & Effective hydraulic conductivity of the channel $(\mathrm{mm} / \mathrm{hr})$ \\
4 & GWQMN & The threshold water level in the shallow aquifer for baseflow $\left(\mathrm{mm} \mathrm{H}_{2} \mathrm{O}\right)$ \\
5 & ESCO & Soil evaporation compensation coefficient \\
6 & SOL_AWC & Available water capacity \\
7 & CH_EROD & Channel erodibility factor \\
\hline
\end{tabular}

Table 3. Diffuse pollution in a tributary level in the districts of Krishna and West Godavari, andhra pradesh

\begin{tabular}{llllll}
\hline $\begin{array}{l}\text { Tributary River } \\
\text { Basin }\end{array}$ & $\begin{array}{l}\text { Sub-basins } \\
\text { included }\end{array}$ & $\begin{array}{l}\text { Ranked sub- } \\
\text { basins for } \\
\left(\mathbf{N O}_{3} \mathbf{N}\right)\end{array}$ & $\begin{array}{l}\mathbf{N O}_{3}-\mathbf{N} \\
\mathbf{( k g / h a / y r )}\end{array}$ & $\begin{array}{l}\text { Ranked } \\
\text { sub-basins } \\
\text { for }(\mathrm{TP})\end{array}$ & $\begin{array}{l}\mathrm{TP} \\
\mathbf{( k g} / \mathbf{h a} / \mathbf{y r})\end{array}$ \\
\hline Ramileru River & 12,14 & 1 & 238.8 & 3 & 16.5 \\
Budameru River & $15,16,17,18,19$ & 2 & 118.3 & 2 & 28.1 \\
Thammileru River & $5,6,13$ & 3 & 64.4 & 1 & 31.2 \\
Minor Drain & $1,2,3,4,8,9,11,20$ & 4 & 19.5 & 4 & 7.43 \\
Gunderu River & 7,10 & 5 & 8.5 & 5 & 2.85 \\
\hline
\end{tabular}



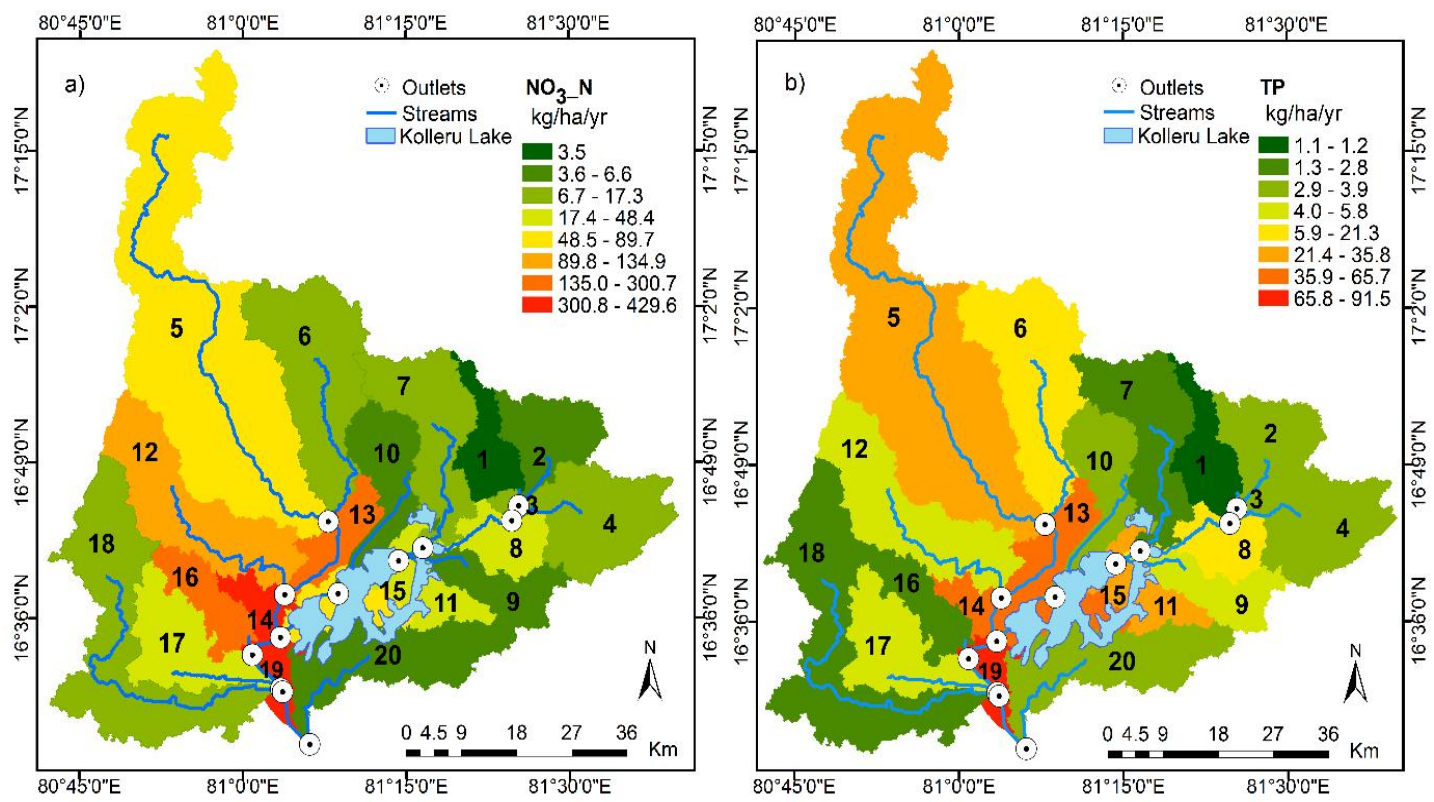

Fig. 3. Spatial distribution of diffuse sources of a) nitrate-nitrogen and b) and total phosphorus load in the Kolleru Lake catchment (2008-2014)

The spatial distribution of mean annual TP (Fig. 3b) in the Kolleru Lake catchment varied from one sub-basin to another, ranging from 1.1 $\mathrm{kg} / \mathrm{ha} / \mathrm{yr}$ to $91.5 \mathrm{~kg} / \mathrm{ha} / \mathrm{yr}$ respectively. The highest TP load was established in the Thammileru basin, with up to $45 \mathrm{~kg} / \mathrm{ha} / \mathrm{yr}$ in some sub-basins, and the corresponding lowest values within the Gunderu basin, with less than 5.5 $\mathrm{kg} / \mathrm{ha} / \mathrm{yr}$ in each sub-basin. The Thammileru basin is accounted for the highest annual precipitation, which enabled the large wet deposition of $P$. The areas with high intensities load of TP mainly concentrated in the paddy fields with conventional tillage patterns and massive use of fertilizers. Similar to the $\mathrm{NO}_{3} \mathrm{~N}$, the highest contribution of TP origin from the sub-basins No. 19, 14, 13, 11, 15, 5, 6, and 8, accounted $>16.5 \mathrm{~kg} / \mathrm{ha} / \mathrm{yr}$. The cause of the difference in sub-basin loads was observed in the Kolleru lake catchment related to human activities. Additionally, the soil data obtained from the National Bureau of Soil Survey identified that $\mathrm{N}$ and $\mathrm{P}$ distribution in the soil types do have close spatial interaction with diffuse pollution. The higher intensity load of these soils is associated with higher export amounts of pollutants from sub-basins. Therefore, this must be considered for conservation practices. Moreover, the agricultural land was disturbed by the frequent cropping and harvesting as well as by fertilizer application. The TP load from medium to maximum variation of the sub-basins is similar to the $\mathrm{NO}_{3} \mathrm{~N}$, which is distributed into the mainstream channel.

The intensity of agricultural land use has a crucial factor in $\mathrm{NO}_{3} \mathrm{~N}$ \& TP exports. Many catchments worldwide show an explicit positive correlation between $\mathrm{N}$ \& $\mathrm{P}$ loss and cropland percentage $[44,45,46]$. In the Kolleru Lake catchment area, having medium to maximum variations of $\mathrm{NO}_{3} \mathrm{~N} \& \mathrm{TP}$ loads observed in each sub-basin level followed by the percentage of various land uses (Fig. 4). Sub-basins with a higher percentage of paddy fields result in higher $N$ \& $P$ exports in the Ramileru and the Thammileru basins. Li et al. (2018) [44] also show a low percentage of paddy fields, resulting in less amount of TN. However, the intensity of frequent fertilizer usage significantly impacts the sub-basins nutrient level exports and catchment characteristics as well.

\subsection{Determination of HRU Level BMPs}

The BMPs priority areas were identified by the method SWAT on the HRU level as paddy cultivated lands where the amounts of $\mathrm{NO}_{3} \mathrm{~N}$ \& TP emissions are the highest. Here, the priority levels were divided based on the watershed area into two types, which is irrigated under net irrigated, gross irrigated, and the rain-fed regions. The first BMPs priority level is the area cultivated more than once a year; emission in 
selected HRUs ranged from 10.5 to $28.3 \mathrm{~kg} / \mathrm{ha} / \mathrm{yr}$ for $\mathrm{NO}_{3} \mathrm{~N}$, while for $\mathrm{TP}$, the emission level ranged from 3.2 to $9.8 \mathrm{~kg} / \mathrm{ha} / \mathrm{yr}$. The second BMPs priority level is where the cropping intensity is higher than $50 \%$ under gross cropped areas ranged from 1.2 to $10.5 \mathrm{~kg} / \mathrm{ha} / \mathrm{yr}$ for $\mathrm{NO}_{3} \mathrm{~N}$, while for TP ranged from 0.5 to 3.2 $\mathrm{kg} / \mathrm{ha} / \mathrm{yr}$ (Fig. 5a and b).

According to Fig. 5a, the majority of selected $\mathrm{HRUs}$ of $\mathrm{NO}_{3} \mathrm{~N}$ were clustered around the lake area. Subsequently, they cause the eutrophication of the lake and led to increasing weed distribution. On the priority of HRUs distribution, higher $\mathrm{NO}_{3} \mathrm{~N}$ load contributing areas were concentrated in the northern and middlewestern villages of the catchment. Among them, the outstanding villages were located in the Ramileru and the Thammileru basins. In these two sub-basins, specific topographic features play an essential role in the highest $\mathrm{NO}_{3} \mathrm{~N}$ emission. Besides, the main inflow rivers
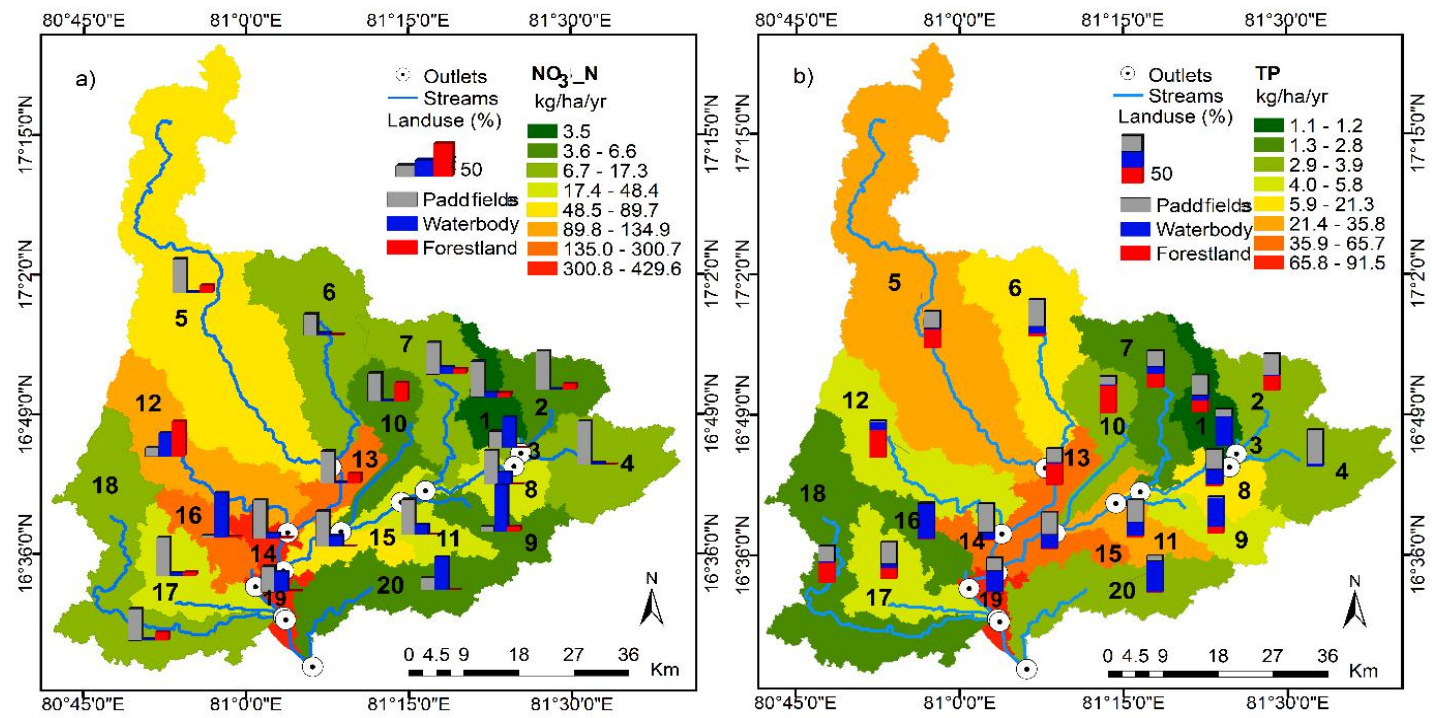

Fig. 4. Spatial distribution of $\mathrm{NO}_{3} \mathrm{~N} \& \mathrm{TP}$, and percentage of land-use types in sub-basins
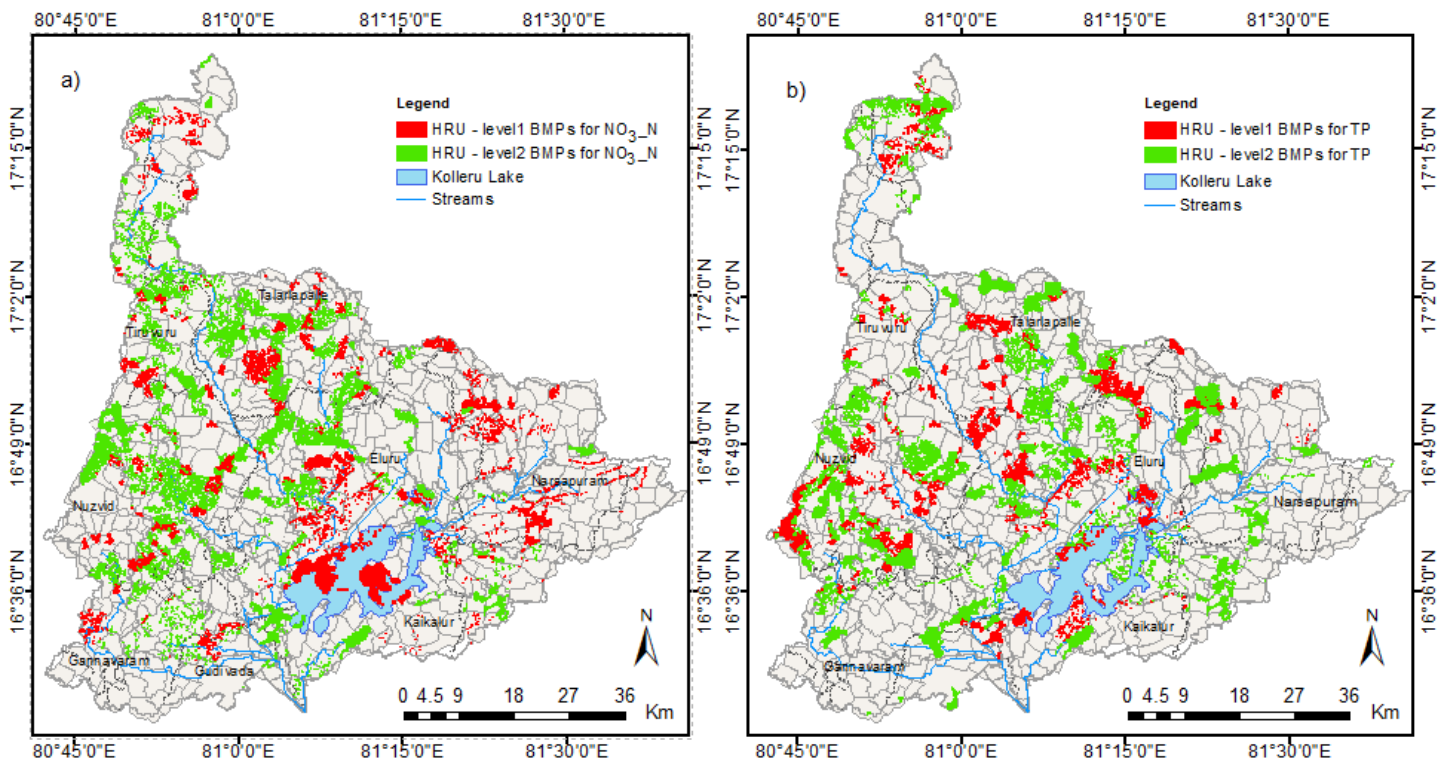

Fig. 5. Spatial distribution of HRU priority levels for BMPs of a) nitrate-nitrogen and b) total phosphorus in the kolleru lake catchment against village level division 
contributing the water to the lake passes through these villages, are the Budameru River $(5.5 \%$ of total $\mathrm{NO}_{3} \mathrm{~N}$ in 2010), the Thammileru River (22.7\% of total $\mathrm{NO}_{3} \mathrm{~N}$ in 2010 ), and partially the Ramileru River (19.2\% of total $\mathrm{NO}_{3} \mathrm{~N}$ in 2010). Moreover, the diversified irrigation network canals connected to the mainstream of the river can easily extract the nutrient onto the river and nitrate loads into the lake. In contrast, the flow contribution of $\mathrm{NO}_{3} \mathrm{~N}$ from the eastern villages are low, because of the migration ability of pollutants are limited there.

The TP emissions are spatially distributed (Fig. $5 \mathrm{~b}$ ) and partially overlapped with the regions of $\mathrm{NO}_{3} \mathrm{~N}$. The majority of TP emissions are primarily concentrated in the middle reaches of the catchment. Approximately 534 village communities were located in the catchment area. Most of the regions are under gross irrigated. At certain stages, early-season drought changed the behavior of the farmers to apply the watersoluble fertilizers (NPK-nitrogen, phosphorus, and potassium), the ratio of 19-19-19, 20-20-20, and 21-21-21 to supplement nutrition. The soil absorbs the $\mathrm{N}$ and $\mathrm{P}$ to enrich during the plant growth time period, and unleash the soluble compounds at the time of flooding period by surface runoff. In the catchment, topographic properties play a key role, because of moderate slopes as well as more than $>46.7 \%$ of the catchment area is mostly extended to the welldrained condition, hence, nonporous in nature, contributed to high $\mathrm{NO}_{3} \mathrm{~N} \&$ TP emissions as a result of surface runoff.

\subsection{Temporal Characteristics of Diffuse Pollutants}

The annual amount of $\mathrm{NO}_{3} \mathrm{~N} \& \mathrm{TP}$, including streamflow, were simulated in Fig. 6a, which illustrates the annual distribution of diffuse pollution from 2008 to 2014 in the Kolleru Lake catchment. The distribution of the $\mathrm{NO}_{3} \mathrm{~N}$ was very uneven between different years. During wet years higher peak values van be observed than in the dry years. The $\mathrm{NO}_{3} \mathrm{~N}$ was relatively consistent with the runoff. Therefore, to assess the possible relation between the $\mathrm{NO}_{3} \mathrm{~N}$ and the runoff, a simple Pearson's correlation analysis was performed. The results show a strong correlation between the $\mathrm{NO}_{3} \mathrm{~N}$ and the streamflow $(r=0.89, p<0.01)$, which means that the $\mathrm{NO}_{3} \mathrm{~N}$ was primarily governed by the runoff (Fig. $6 \mathrm{~b})$. Hence, the result was justified with other studies $[47,48,49]$. The correlation between the TP and the runoff (Fig. 6c) is also high $(r=0.84, p<0.01)$, but lower than the $\mathrm{NO}_{3} \mathrm{~N}$ and the runoff. This can be attributed to the agricultural water diversion system, and a mode of severe nutrient transport. However, during the wet period (July 2010, August 2011), the runoff is relatively high and subsequently resulted in a high nutrient export, which can be transported by a stream network and accumulated near to the downstream area of the lake. $\mathrm{NO}_{3} \mathrm{~N}$ sources are the chemical fertilizers used in agricultural fields, especially for paddy cultivation followed by Cotton, Maize, and Chillies, in the Kolleru Lake catchment. The upward trend of $\mathrm{NO}_{3} \mathrm{~N}$ load in June 2010, resulting from the heavy precipitation recorded during that month, according to the data derived from the Indian Meteorological Department, might be responsible for the higher nitrate export load. Industrial pollution, excessive fertilizer application, and chemical usage of fishponds to enrich the fish growth contribute in significant quantities to the nutrient loads. The primary reasons for high nutrient flow in the catchment are both frequent land-use changes, intensive paddy cultivation, and the two large rivers Krishna and Godavari.

\subsection{Suggestions for Pollution Mitigation Measures}

Suggestive measures for adequate pollution mitigation plans can be drawn from the results of critical sub-basins and the HRU priority areas as well. This study emphasized that improved agricultural management practices are necessary for the whole catchment area. There are numerous methods to improve the agricultural practices that can be adopted by farmers to prevent nutrient losses from croplands [50]. However, management practices can be targeted on agricultural lands and the development of proper land use planning and zoning practices in sub-basins. Furthermore, the implementation of buffer strips and the management of water margins to reduce surface runoff from fields are essential measures to achieve environmental improvements $[51,52,53]$. The buffer width, the slope gradient, and the vegetation type are difficult to site conditions for designing an adequate buffer. However, an increasing buffer width would increase sediment removal efficiency [52]. Vegetated buffers are widely used for better agricultural practices to reduce diffuse source pollution from runoff [54]. However, these effective mitigation buffer measures of nutrient losses are still rarely implemented in India $[53,55]$. 


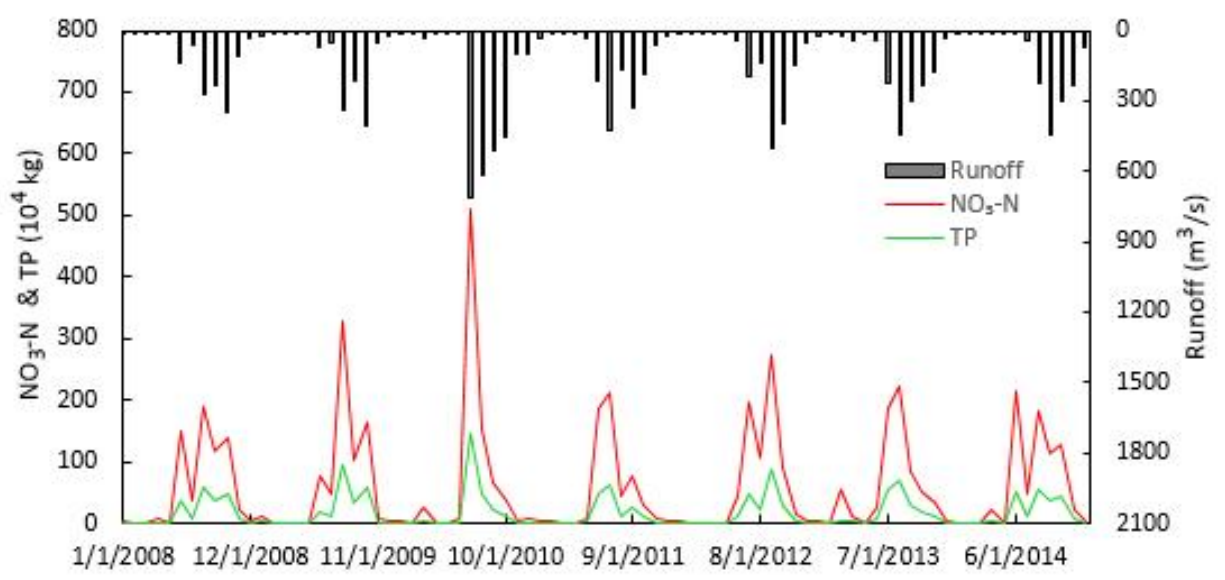

a)

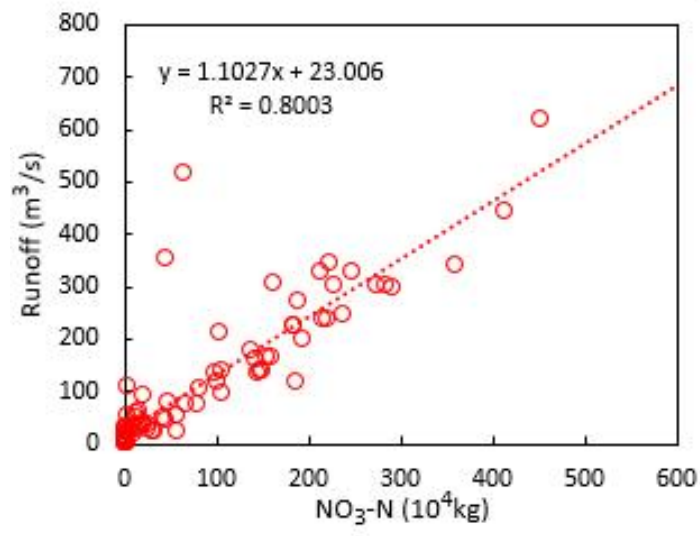

b)

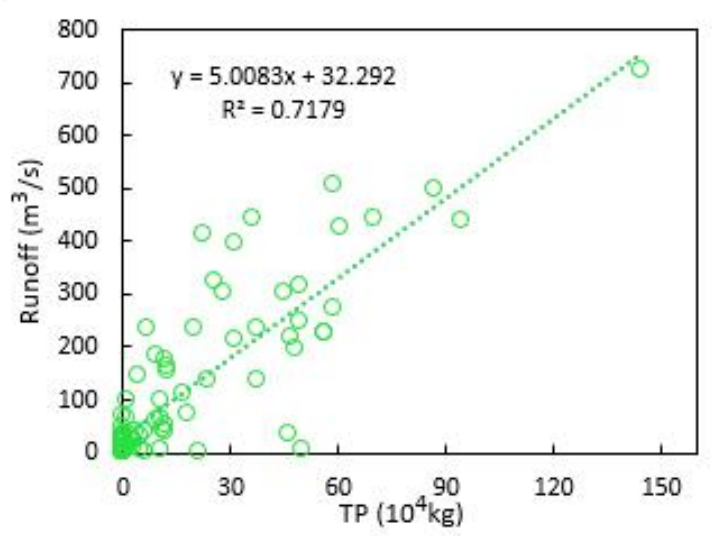

c)

Fig. 6. Relationships between a) runoff vs. nutrient fluxes in the kolleru lake catchment b) runoff vs. $\mathrm{NO}_{3} \mathrm{~N}$ relationship c) runoff vs. TP during the period of 2008-2014

To reduce the chemical pesticide consumption in Andhra Pradesh state, between 1999 and 2005, the European Union had conducted the "NonPesticide Management in Andhra Pradesh, India" in the cooperative project of the German Council for Sustainable Development and Centre for Sustainable Agriculture (CSA). The potential outcome of this program was to enlighten the farmers to use natural pesticides, such as neem (Azadirachta indica) and chili-garlic extracts, rather than intensive use of chemical fertilizers. Therefore, the positive results caused increased biodiversity, no adverse effects on the environment, preventing soil erosion, and improving soil fertility. This study further suggests the implementation of the "Non-pesticide management" practices in the Kolleru Lake catchment. However, this kind of institutional practice for empowering rural people, imparting training to farmers, and laying demonstrations are essential for the growth of sustainable management. Besides, the catchment comprises of 534 villages of which not even more than $>20 \%$ adopted the conventional irrigation methods. Moreover, this study identified the HRUs level priority areas along with critical subbasin measures, which should be analyzed and implemented. For minimizing the environmental crisis, also a forest area has suggested around the $3 \mathrm{ft}$ contour level of the lake. Thus, it provides shelters for the 20 million immigrant, international birds as well as to conserve the environmental lake ecosystem.

Additionally, the Government of India notified that only the conventional method of fishing activities should allow around the lake, following the law of G.O.Ms.No.120, dated 4.10.1999. For this purpose, the Kolleru Fisherman Cooperative Society (KFCS) should follow the standards laid down by the Ministry of Environment, Government of India, to bring back the Kolleru 
Lake to its near-pristine condition. Moreover, adequate steps should be taken for stoppage and regulation of industrial pollutants from nearby towns. Furthermore, the villages surrounded by the lake must be classified as zones for BMPs.

\section{CONCLUSION}

From the above-mentioned suggestions, it can be concluded that the management of agricultural practices is required to adapt to the whole catchment region. The essential features of nutrient runoff from croplands should take into consideration the protection of the lake water quality. Pollution abatement methods, continuous monitoring of point sources pollution, and laying demonstrations to enlighten the public perception towards lake degradation would be beneficial.

This paper serves as an initial discussion of the diffuse pollution in the Kolleru Lake catchment. The results of SWAT modeling showed that $28 \%$ of the highest $\mathrm{NO}_{3} \mathrm{~N}$ load contributed from the Ramileru basin, and $32 \%$ of TP load from the Thammileru basin, which make them to the critical river basins of diffuse pollution. Among them, the average load of individual sub-basins is estimated. This study indicated that diffuse pollutions are mainly governed by agricultural runoff. Apart from that, HRU priority level critical sources of $\mathrm{NO}_{3} \mathrm{~N}$ and TP were identified against the village communities. Besides, the first and second priority levels of BMPs of diffuse sources were highlighted. These results improve the understanding of pollution levels and targeting control measures of critical priority areas in the Kolleru Lake catchment. The communication between the stakeholders and water quality control managers are required for knowledge exchange. This is a model introduced based on a profound understanding of the ecological crisis of lake degradation levels, and a prerequisite for the development of further implementation measures.

\section{LIMITATIONS}

The Kolleru Lake catchment is an ungauged type, sufficient calibration, and validation of the SWAT model are limited. Unfortunately, there exists still a lack of observed data for nutrient load, especially for the discharge depending on nutrient load. However, the study was conducted based on original data, acquired from Indian Organizations, with promising the results obtained from the SWAT model. This is the initial study conducted for the whole Kolleru Lake catchment level, regards certain assumptions that were made in terms of catchment delineation boundaries and the crop fertilization period. Field investigations on the interaction of pollutant loads with the runoff should be taken into consideration for a better calculation of the pollutant load.

\section{ACKNOWLEDGEMENTS}

The authors would like to thank the anonymous reviewers for their review and constructive comments related to this manuscript. We are indebted to the Government of India for providing us with necessary datasets and information to accomplish this work.

\section{COMPETING INTERESTS}

Authors have declared that no competing interests exist.

\section{REFERENCES}

1. Parker D. Introduction of new process technology into the wastewater treatment sector. Water Env. Res. 2011;483-497.

2. Barton DN, Saloranta T, Bakken TH, Solheim AL, Moe J, Selvik JR, Vagstad N. Using Bayesian network models to incorporate uncertainty in the economic analysis of pollution abatement measures under the water framework directive. Water Supply. 2005;5:95-104.

3. Hettige H, Huq M, Pargal S, Wheeler D. Determinants of pollution abatement in developing countries: Evidence from South and Southeast Asia. World Development. 1996;24:1891-1904.

4. Forum WE. World Economic Forum Annual Meeting. A report on the state of water pollution is killing millions of Indians. Here's how technology and reliable data can change that. India Economic Meeting. India; 2019.

5. Board CPC. Status of water quality in India 2016. Central Pollution Control Board, Ministry of Environment, Forest and Climate Change, Government of India. Government of India, New Delhi; 2016.

6. Bassi N, Kumar MD, Sharma A, Saradhi PP. Status of wetlands in India: A review of extent, ecosystem benefits, threats, and management strategies. Journal of Hydrology: Regional Studies. 2014;2:1-19.

7. Wang $X$, Zhang $W$, Huang $Y, L i ~ S$. Modeling and simulation of point-non-point source effluent trading in Taihu Lake area: 
The perspective of non-point source control in China. Science of The Total Environment. 2004;325:39-50.

8. Fang J, Li G, Rubinato M, Ma G, Zhou J. Jia G, Yu X, Wang H. Analysis of long-term water level variations in Qinghai Lake in China. Water. 2019;11(10):2136.

9. Tu J. The combined impact of climate and land-use changes on streamflow and water quality in eastern Massachusetts, USA. Journal of Hydrology. 2009;379:268-283.

10. Zampella R, Procopio N, Lathrop R, Dow C. Relationship of land-use/land-cover patterns and surface-water quality in the Mullica river basin. J. of American. Water. Reso. Asso. 2007;43:594-604.

11. Hoyer $R$, Chang $H$. Assessment of freshwater ecosystem services in the Tualatin and Yamhill basins under climate change and urbanization. Applied Geography. 2014;53:6:402-41.

12. Holopainen $\mathrm{R}$, Lehtiniemi $\mathrm{M}$, Meier $\mathrm{M}$, Albertsson J, Gorokhova E, Kotta J, Viitasalo M. Impacts of changing the climate on the non-indigenous invertebrates in the northern Baltic Sea by the end of the twenty-first century. Biological Invasions. 2016;18:3015-3032.

13. Liao J, Shen G, Li Y. Lake variations in response to climate change in the Tibetan Plateau in the past 40 years. International Journal of Digital Earth. 2012;6:534-549.

14. Gilboa Y, Gal G, Friedler E. Defining limits to multiple and simultaneous anthropogenic stressors in a lake ecosystem-Lake Kinneret as a case study. Environmental Modelling \& Software. 2014;61:424-432.

15. Banadda N, Nhapi I, Wali UG. Characterization of non-point source pollutants and their dispersion in Lake Victoria: A case study of the Gaba Landing site in Uganda. IFAC Proceedings Volumes. 2010;43:455-460.

16. Rees $M$, Roe $J H$, Georges $A$. Life in the suburbs: Behavior and survival of a freshwater turtle in response to drought and urbanization. Biological Conservation. 2009;142:3172-3181.

17. Taylor SD, He Y, Hiscock KM. Modeling the impacts of agricultural management practices on river water quality in Eastern England. J. Env. Management. 2016;180: 147-163.

18. Guo J, Wu F, Luo X, Liang Z, Liao H, Zhang R, Li W, Zhao X, Chen S, Mai B. Anthropogenic input of polycyclic aromatic hydrocarbons into five lakes in Western China. Environ. Pollution. 2010;158:21752180.

19. Shen Z, Chen L. Hong Q, Qiu J, Xie H, Liu $R$. Assessment of nitrogen and phosphorus loads and casual factors from different land use and soil types in the Three Gorges Reservoir area. Science of the Total Environment. 2013;454-455:383-392.

20. Randhir TO, Tsvetkova O. Spatiotemporal dynamics of landscape pattern and hydrologic process in watershed systems. Journal of Hydrology. 2011;404:1-12.

21. Arnold JG, Srinivasan R, Muttiah RS, Williams JR. Large-area hydrologic modeling and assessment part-1: model development. J. Am. Water Resour. Assoc. 1998;34:73-89.

22. Coffey R, Dorai-Raj S, O'Flaherty V, Cormican M, Cummins E. Modeling of pathogen indicator organisms in a smallscale agricultural catchment using SWAT. Human and Ecological Risk Assessment: An International Journal. 2013;19/1:232253.

23. Shang $X$, Wang $X$, Zhang $D$, Chen W, Chen $X$, Kong $H$. An improved SWATbased computational framework for identifying critical source areas for agricultural pollution at the lake basin scale. Ecological Modelling. 2012;226:110.

24. Kang MS, Park S, Lee JJ, Yoo KH. Applying SWAT for TMDL programs to a small watershed containing rice paddy fields. Agricultural Water Management. 2006;79:72-92.

25. Abbaspour KC, Rouholahnejad E, Vaghefi $\mathrm{S}$, Srinivasan $\mathrm{R}$, Yang $\mathrm{H}$, Kløve B. A continental-scale hydrology and water quality model for Europe: Calibration and uncertainty of a high-resolution large-scale SWAT model. Journal of Hydrology. 2015; 524:733-75.

26. Yalew S, Griensven A, Ray N, Kokoszkiewicz L, Betrie G. Distributed computation of large scale SWAT models on the Grid. Environ. Model \& Soft. 2013; 41:223-230.

27. Liu $\mathrm{Y}$, Guo $\mathrm{T}$, Wang $\mathrm{R}$, Engel BA, Flanagan D, Li S, Pijanowski BC, Collingsworth PD, Lee JG, Wallace CW. A SWAT-based optimization tool for obtaining cost-effective strategies for agricultural conservation practice implementation at watershed scales. Scie. Total. Envi. 2019;691:685-696. 
28. Wallace CW, Flanagan DC, Engel B. Quantifying the effects of conservation practice implementation on predicted runoff and chemical losses under climate change. Agri. Water. Management. 2017; 186:51-65.

29. Barman R. The fishes of the Kolleru Lake, Andhra Pradesh, India, with comments on their conservation. Rec. Zool. Sur. India. 2004;103(Part 1-2):83-89.

30. Vijayalakshmi BBRG, Brahmaji RP. Evaluation of Physico-chemical parameters to determine the water quality criteria in Kolleru Lake A.P, India. Int. Journal of Engineering Research and Application. 2017;7:7-12.

31. Krishna PV, Panchakshari V, Suresh P, Prabhavathi K, Kumar KA. Ichthyofaunal diversity of Siluriformes from Kolleru Lake, Andhra Pradesh, India. International Journal of Fisheries and Aquatic Studies. 2016;4(6):420-424.

32. Board CP. Functions of CPCB. New Delhi; 2005.

33. M. O. E, MoEF F. The legal and regulatory framework for environmental protection in India; 2007.

34. Azeez PA, Kumar AS, Choudhury BC, Sastry VNVK, Upadhyay S, Reddy KM, Rao KK. Report on the proposal for downsizing the Kolleru Wildlife Sanctuary (+5 to +3 feet contour). Report submitted to The Ministry of Environment; 2011.

35. Rao A. Environmental degradation of Kolleru lake. Allied Publishers Pvt. Ltd., Hyderabad; 2005.

36. Sreenivas N, Kumar PA. Conservation of Lake Kolleru: A status report. Int. J. Res. Sci. Technol. 2013;2:138-141.

37. Jayanthi $M$, Rekha $P$, Kavitha N, Ravichandran P. Assessment of the impact of aquaculture on Kolleru Lake (India) using remote sensing and Geographical Information System. Aquaculture Research. 2006;37:1617-1626.

38. Rao A, Pillala R. The concentration of pesticides in sediments from Kolleru Lake in India. Pest Management Science. 2001; 57:620-624.

39. Narender K. The broken mirror. Down to Earth. 1993;2.

40. RIS. Ramsar Information Service; 2002.

41. Gassman PW, Reyes MR, Green $\mathrm{CH}$, Arnold JG. The soil and water assessment tool: Historical development, applications, and future research directions. Economics Publications. 2007;4:1211-1250.
42. Williams JR. Flood routing with variable travel time or variable storage coefficients. Trans ASABE. 1976;12:100-103.

43. Kolli M, Opp C, Groll M. Mapping of potential groundwater recharge zones in the Kolleru Lake catchment, India, by using remote sensing and GIS techniques. Natural Resources. 2020;11(03):127-145.

44. Li W, Zhai L, Lei Q, Wollheim WM, Liu J, Liu $\mathrm{H}$, Hu W, Ren $\mathrm{T}$, Wang $\mathrm{H}$, Liu $\mathrm{S}$. Influences of agricultural land use composition and distribution on nitrogen export from a subtropical watershed in China. Science of the Total Environment. 2018;642:21-32.

45. Chen $\mathrm{BH}$, Chang SX, Lam SK, Erisman JW, Gu BJ. Land use mediates riverine nitrogen export under the dominant influence of human activities. Environ. Res. Lett. 2017;12:94018.

46. Harrison JA, Maranger RJ, Alexander RB, Giblin AE, Jacinthe PA, Mayorga E, Seitzinger SP, Sobota DJ, Wollheim WM. The regional and global significance of nitrogen removal in lakes and reservoirs. Biogeochemistry. 2009;93:143-157.

47. Qin G, Liu J, Wang T, Xu S, Su G. An integrated methodology to analyze the total nitrogen accumulation in a drinking water reservoir based on the SWAT model driven by CMADS: a case study of the Biliuhe reservoir in Northeast China. Water. 2018; 10:1535.

48. Navarro ME, Trolle D, Pérez MS, Merlin SA, Jeppesen E. Hydrological and water quality impact assessment of a Mediterranean limno-reservoir under climate change and land use management scenarios. Journal of Hydrology. 2014;509: 354-366.

49. Helmreich B, Hilliges R, Schriewer A, Horn $H$. Runoff pollutants of a highly trafficked urban road-correlation analysis and seasonal influences. Chemosphere. 2010; 80:991-997.

50. Izydorczyk K, Hejduk DM, Jarosiewicz P, Bydalek F, Fratczak W. Extensive grasslands as a useful measure for nitrate and phosphate reduction from highly polluted subsurface flow-case studies from Central Poland. Agricultural Water Management. 2018;203:240-250.

51. McCracken DI, Cole LJ, Harrison W, Robertson D. Improving the farmland biodiversity value of riparian buffer strips: Conflicts and compromises. J. Environ. Qual. 2012;41:355-363. 
52. Zhang $X$, Liu $X$, Zhang $M$, Dahlgren $R$, Eitzel M. A review of vegetated buffers and a meta-analysis of their mitigation efficiency in reducing nonpoint source pollution. J. Environ.Qual. 2010;39: 76-84.

53. Anbumozhi V, Radhakrishnan J, Yamaji E. Impact of riparian buffer zones on water quality and associated management considerations. Ecological Engineering. 2005;24:517-523.
54. Balestrini R, Arese C, Delconte CA, Lotti A, Salerno F. Nitrogen removal in subsurface water by narrow buffer strips in the intensive farming landscape of the Po River watershed, Italy. Ecological Engineering. 2011;37:148-157.

55. Bhojvaid PP, Timmer VR, Singh G. Reclaiming sodic soils for wheat production by Prosopis juliflora (Swartz) DC afforestation in India. Agroforest Syst. 1996;34:139-150.

(c) 2020 Kolli et al.; This is an Open Access article distributed under the terms of the Creative Commons Attribution License (http://creativecommons.org/licenses/by/4.0), which permits unrestricted use, distribution, and reproduction in any medium, provided the original work is properly cited.

Peer-review history:

The peer review history for this paper can be accessed here: http://www. sdiarticle4.com/review-history/58126 